\title{
An assessment of ethno-medicinal plants used by Sardar and Malaha communities of Koshi Tappu Wildlife Reserve, Province No. 1, Nepal
}

\author{
Deependra Joshi* and Uzabi Baidar \\ MNJ electronical and hyderalic consultant, India \\ Submission: October 15, 2018; Published: December 14, 2018 \\ *Corresponding author: Deependra Joshi, MNJ electronical and hyderalic consultant, India
}

Abstract

Medicinal plants play an important role in the healthcare practices amongst the rural population of Nepal. This knowledge has been passed from generation to generation in verbal form only and is not documented in any form. The objective of this study was to assess ethno-medicinal plants used by Malaha and Sardar communities of Sunsari district of Province No. 1. A total of 40 plant species belonging to 35 genera and 24 family have been recorded as medicinal plants traditionally used by these communities for treatment of various ailments. Different parts of medicinal plants in different forms were reported to be used for the treatment of 27 types of various health system disorders. Traditional healers and elderly people were well experienced in traditional method of using medicinal plants but they were worried about negligence of people towards such traditional use of valuable medicinal plants. It can be concluded from this study that the Malaha and Sardar communities of Sunsari district inherit a rich traditional knowledge and documentation of this knowledge has provided novel information of that area.

\section{Introduction}

Koshi Tappu Wildlife Reserve (KTWR) is located in the alluvial flood plain of Sapta Koshi River with an area of 175sq. km span over Sunsari, Saptari and Udayapur districts of Eastern Nepal. The reserve, Nepal's first wetland site of international importance listed in the Ramsar Site, is the prime habitat of the last remaining population of wild water buffalo (Bubalus bubalis) and is well acclaimed for hosting congregation of large number of migratory birds and highest number of globally threatened bird species in Nepal. Traditional knowledge on the use of medicinal and aromatic plants has remained most affordable as well as easily accessible source of primary healthcare and treatment, especially amongst the poor communities where the local therapy is the only means of medical treatment [1]. There is a wider recognition on traditional use of medicinal plants in Nepal. Ethno-botany is the science of documentation and conservation of original knowledge which has been using by ethnic people since ancient history [2]. Documentation of indigenous knowledge is important for the conservation of species and sustainable resource use [3] and is significant in revealing locally vital plant species which might contribute in the discovery of crude medicine and even contributing towards economic development [4]. Koshi Tappu Wildlife Reserve is considered to be a natural storehouse of medicinal plants. Indigenous people living in its buffer zone are heavily dependent on the use of wild plants or a specific part to fulfill their healing needs. They highly depend on the nearby wetland and forest areas to supply their needs of medicine, timber, fuelwood, wood, wild vegetable and many more available resources. There is a vast repository of traditional knowledge on medicinal and aromatic plants, including the use of animals for medicine in the study area. However, this information is scarce due to lack of research and documentation. Since time immemorial, these communities have been using this knowledge in case of both food and medicinal purposes and have economic, medicinal and cultural values. In fact, the indigenous people of KTWR possess an immense knowledge of their environments, based on centuries of living close to nature. Living in and from the richness and variety of complex ecosystems, they have good understanding of the properties of plants and animals, the functioning of ecosystems and the techniques for using and managing them that is particular and often detailed.

\section{Objectives of the study}

The objective of this study is the documentation of traditional knowledge and indigenous practices of ethno-medicinal plants by two wetland dependent communities of Koshi Tappu Wildlife Reserve, namely Sardar and Malaha indigenous communities. Specifically, the study was conducted in order to achieve the following objectives:

a) Documentation of medicinal plants and their use pattern and the existing level of traditional knowledge on medicinal plants amongst the wetland dependent communities of KTRW; and

b) Analysis of the participation of the wetland dependent communities and their level of awareness on sustainable management and utilization of medicinal plants and its practices. 


\section{Materials and Methods}

A study on Medicinal and Aromatic Plants (MAPs) was carried out in Koshi Tappu Wildlife Reserve (KTWR) of Eastern Nepal. The data on ethno-medicinal properties of the plant resources was collected by conducting questionnaire survey and interview among the local community of KTWR (78\% > 40 years old), in May 2018.

The study collected plant species and its taxonomic characters and other necessary information were noted down in the field (Figure 1). In order to obtain detailed information, plant specimens collected from the field were exhibited and semistructured interviews were conducted with 25 respondents in Malaha community and 25 respondents in Sardar community of Kusaha rural municipality, mostly represented traditional healers and knowledgeable persons, both male and female. The information collected included local name of plants, its use, form of use, and parts used. The recorded specimens were arranged in alphabetical order with botanical and vernacular name after their family. The parts used along with their value are also described.

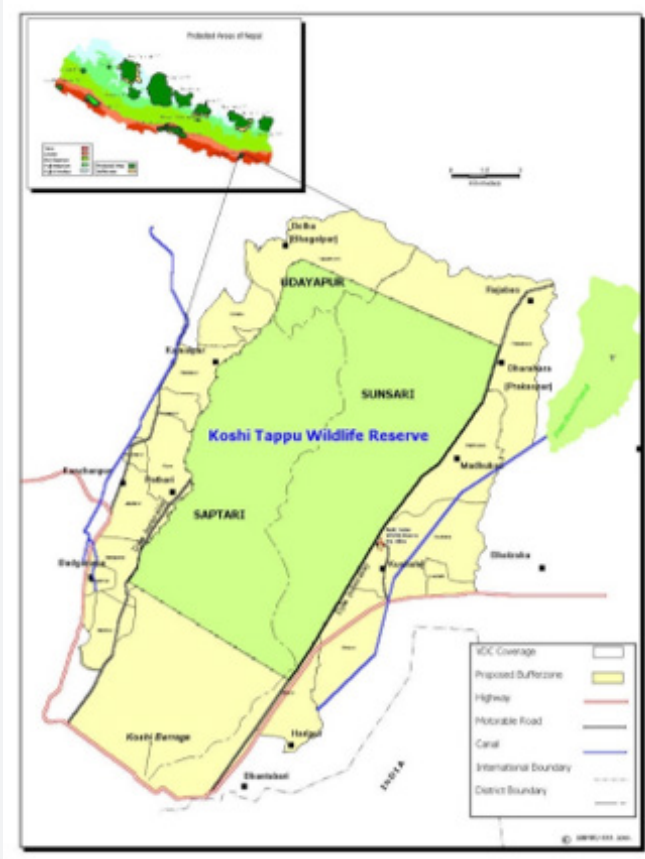

Figure 1

\section{Result and Discussion}

A total of 50 respondents (44 male and 6 female) from Madhuwan and Kusaha villages of Sunsari district participated in the study. Participants included household heads, plant collectors and users. All respondents belonged to Tharu ethnic group, a major group (14\%) of Sunsari District [5]. Majority (56\%) of respondents had no formal education, $6 \%$ were literate, $28 \%$ had primary level education, $6 \%$ had secondary education and $4 \%$ had higher secondary level education (Chart 1-3).

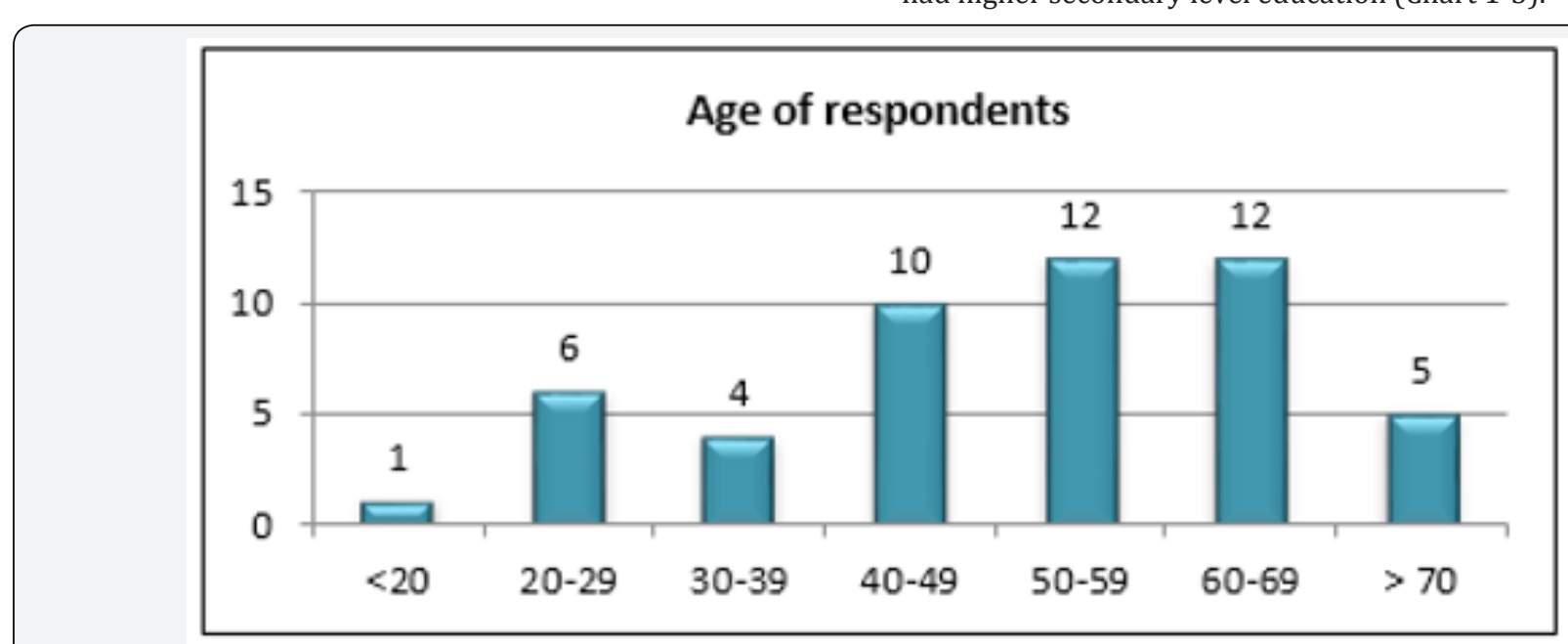

Chart 1: Age of respondents. 


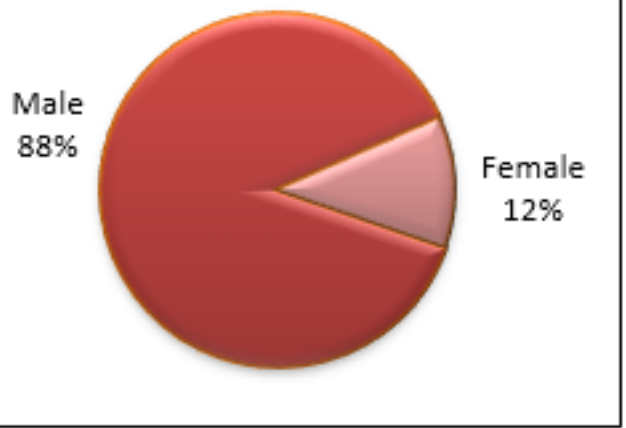

Chart 2: Gender of respondents.

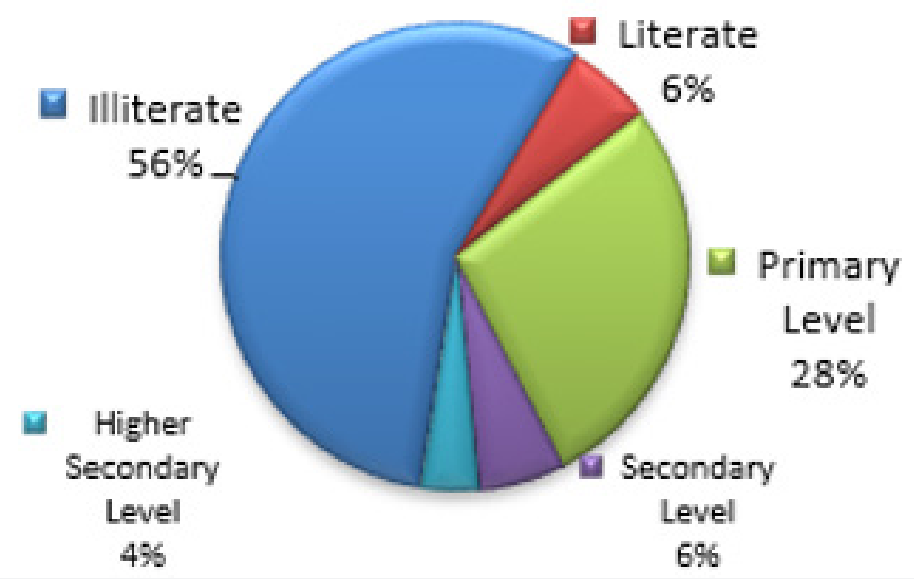

Chart 3: Education status of respondents.

\section{Application of Medicinal Plants}

The structure for questionnaire survey was developed to facilitate information collection. Interviews were carried out to collect information on the use of plant resources, parts used and its methods of utilization. A checklist/inventory was developed and used to determine the available plant resources and application in the treatment of disease or disorder. The study identified a total of
40 medicinal plant species that has been used to prepare a wide variety of remedies. The prevailing life form included trees and herbs. Altogether, 40 plant species belonging to 35 genera and 24 family was identified that was used for both human diseases and livestock treatment. The local name, uses, parts used, and form of uses were noted down. In all, 20 species from Malaha communities and 20 species from Sardar communities were collected.

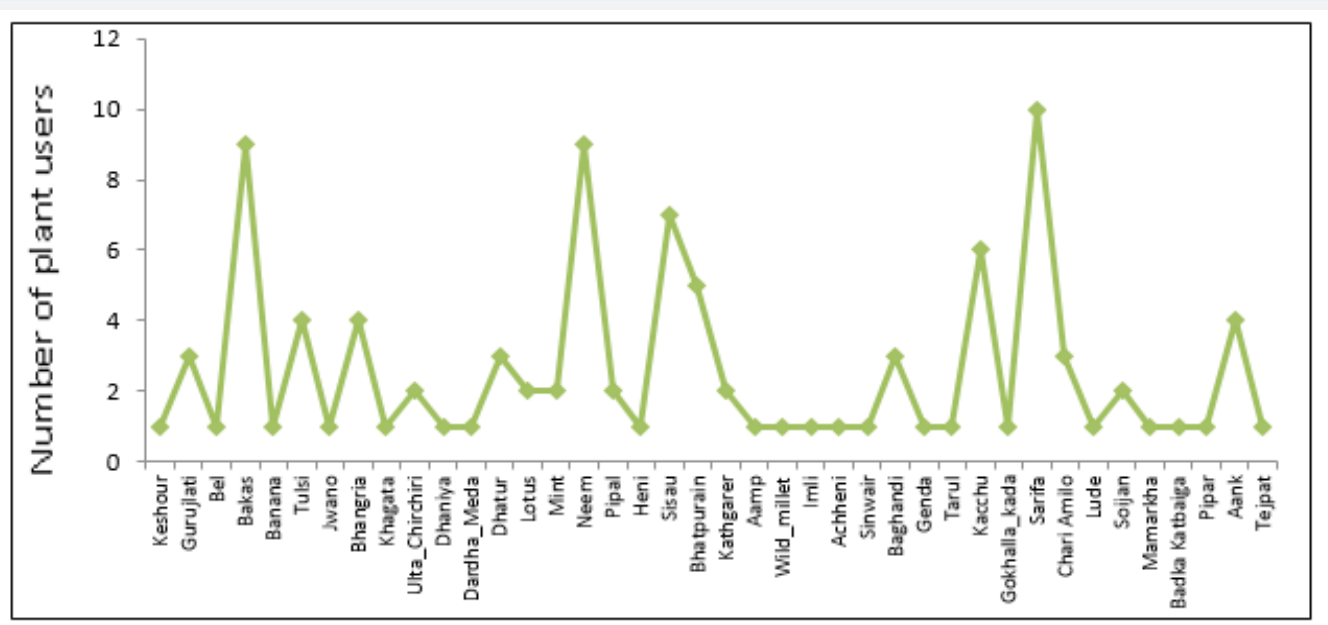

Chart 4: Frequency of use of plant species. 
The recorded plant species (40) were used for edible and medicinal purposes. Besides, the plants were used as fodder, firewood, religious and other miscellaneous household purposes. Some of the most common medicinal uses were in fever, toothache, labor pain, blood pressure, diabetes, lactation, cuts/ wounds, eye problem, etc. Miscellaneous uses include making toothpaste, herbal soap and shampoo, toothbrush of stem, etc. Two of the plants were also found to be used for curing animal diseases. Several species were found to be used for more than one purpose. Uses of plants along with its local name, form of use, and parts used are listed in Annex 1, (Chart 4) Almost all parts: leaf, seeds, bark, flower, root, stem, fruit and milk were used in the preparation of medicinal formulations. Highly used plant part by local people was leaf (53\%), followed by stem (15\%), flower (5\%), seed (7\%), bark (6\%), root (5\%), milk (4\%), fruit (3\%) and whole plant (2\%) (Chart 5).

Chart 5: Parts used.

\section{Ailments Treated and Remedies Formulation}

Cuts and wounds, respiratory problems, gastro-intestinal disorders, cough and cold, fever and headache, menstrual disorders, dermatological infections and dental problems were the main ailments treated with medicinal plants. Dysentery, fever and headache, cuts and wounds, cough and cold and abdominal problems were treated with the highest diversity of medicinal plant species (Table 1). The respondents who participated in the interview were familiar with the plant species used to deal different diseases and disorder. The medicinal plants were used frequently in the form of paste, juice, decoction and mixing with other plant species. In terms of the methods of preparation for medicinal use, $32 \%$ of the plants are concentrated in liquid form by heating or boiling (decoction), paste of $22 \%$ plant species are used, juice of $17 \%$ plants are used for treatment of various diseases, $13 \%$ of the plants is mixed with other substances like lemon juice or milk, $10 \%$ of the identified plant species are blended, $3 \%$ plant species are used in powdered form and smoke of $3 \%$ plant species are used in treatment of various ailments (Chart 6).

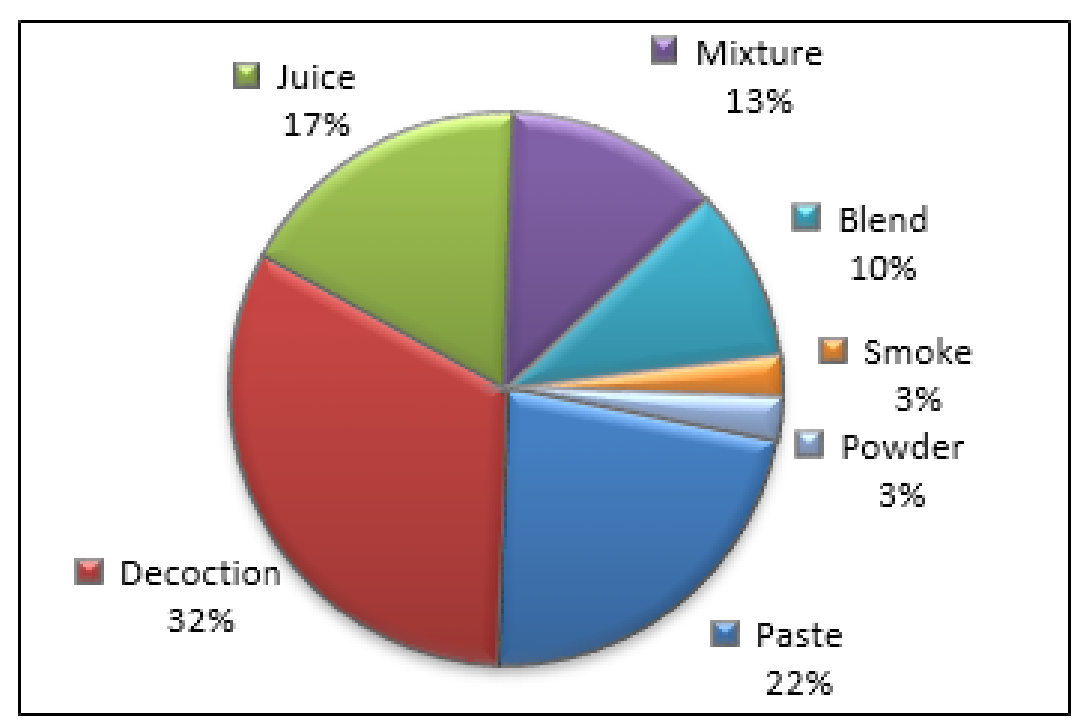

Chart 6: Method of preparation. 


\section{International Journal of Environmental Sciences \& Natural Resources}

Table 1: Medicinal plants used to cure various ailments.

\begin{tabular}{|c|c|c|}
\hline SN & Ailment & Plants \\
\hline & Abortion & Banana \\
\hline & Abdominal problems and digestion & Kathgarer, Sisau, Gurujilati, Gokhalla kada, Chari amilo, Pudina \\
\hline & Acidity & Bhatpurain \\
\hline & Wormicide & Bhatpurain, Bhangria, Kathgarer, Neem, Sarifa \\
\hline & Urinary problems & Sisoo, Bhatpurain, Gokharu \\
\hline & Blood pressure and heart problems & Neem \\
\hline & Bee sting & Sinwair \\
\hline & Common cold and cough & Achheni, Aank, Tulsi, Bakas, Kacchu \\
\hline & Cuts/wound & Darda meda, Baghandi, Neem, Imli, Pipal, Bhangria, Genhwa \\
\hline & Scabies & Bhangria, Sisau, Neem, Badka Katbaigani \\
\hline & Dental problems & Neem, Baghandi \\
\hline & Dysentery & Bhatpurain, Aank, Sisau, Kathgarer, Gurujilati, Dhatur, Bhatpurain \\
\hline & ENT & Baghandi, Genhwa \\
\hline & Energy & Kamal \\
\hline & Weeping illness in children & Mamarkha \\
\hline & Fever and headache & Bakas, Aank, Heni, Kathgarer, Ulta chirchiri \\
\hline & Furuncles & Aank \\
\hline & Gastric and indigestion & Jwano, Kathgarer, Pudina, \\
\hline & Jaundice & Aamp, Makhna \\
\hline & Menstrual disorder & Wild millet, Arahul \\
\hline & Measles & Kacchu \\
\hline & Piles & Aank, Imli \\
\hline & Spermatorrhoea & Gokhalla kada, Kamal \\
\hline & Rheumatism & Soijan \\
\hline & Lactation & Gokharu \\
\hline & For animals & Pipal, Dhatur \\
\hline
\end{tabular}

\section{Profile on Highly Used Plant Species}

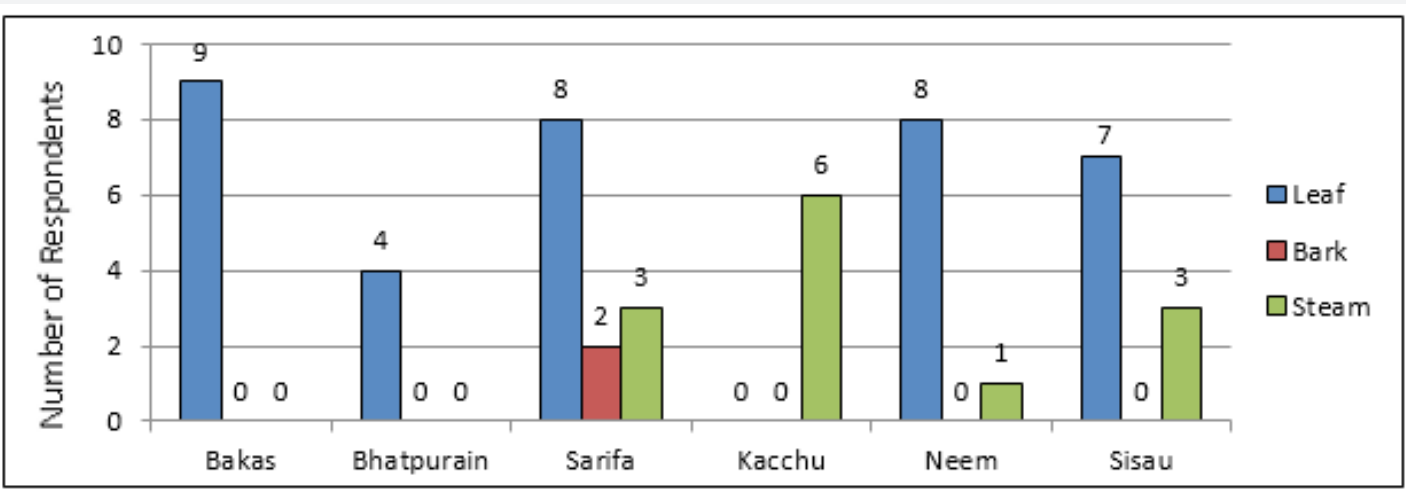

Chart 7: Used parts of selected plant species.

Local community $(\mathrm{N}=50)$ has been using more than one plant species for medicinal purpose. (5/40) plant species have been highly used by the respondents. Medicinal plants have been ranked according to maximum household usage $(\mathrm{N} \geq 5$, where $\mathrm{N}=$ No. of particular plant users among the respondents). Local residents have been highly using leaf in several ailments. They have been highly using the plant species in treatment of common cold and cough (Table 2) and (Charts $7 \& 8$ ). The respondents have been receiving the knowledge on the use of plant species through elders, family tradition, community knowledge and traditional knowledge holders (Table 3). 


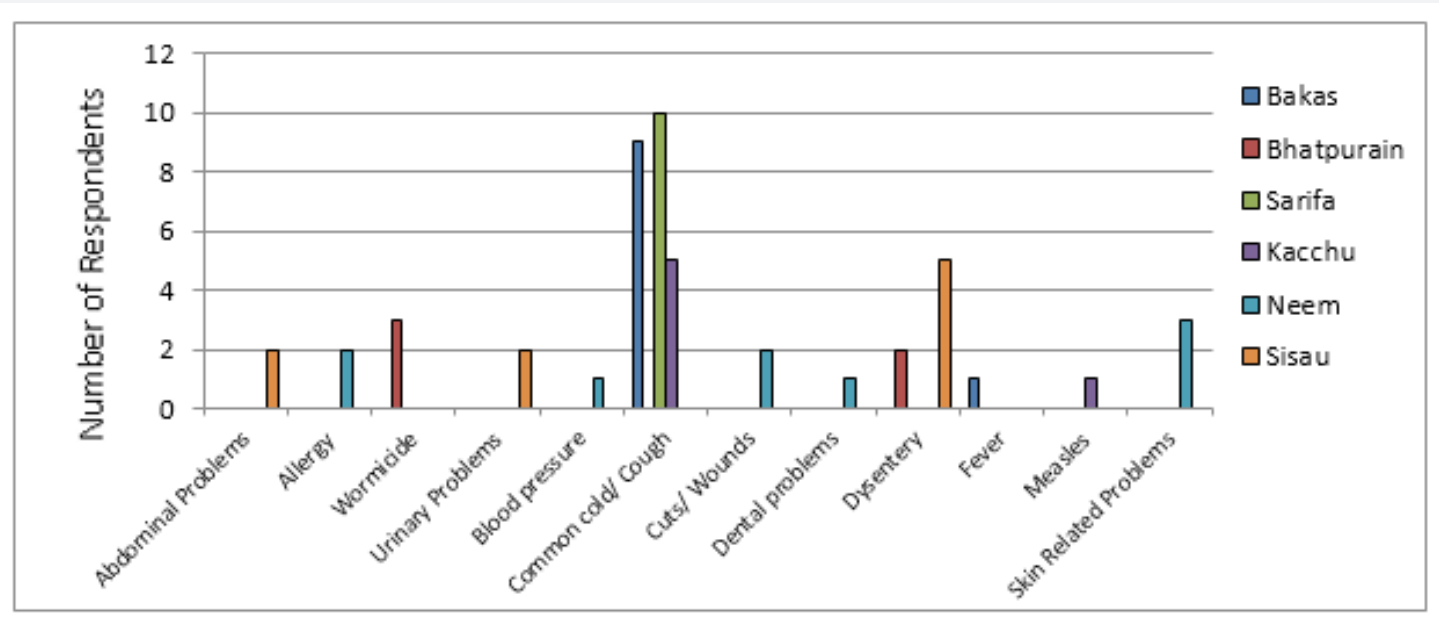

Chart 8: Ailments associated with selected plant species.

Table 2: Highly used plant species.

\begin{tabular}{|c|c|c|c|c|c|c|}
\hline \multirow{2}{*}{ Medicinal/ Aromatic Plants } & \multicolumn{2}{|c|}{ Included } & \multicolumn{3}{|c|}{ Excluded } & \multicolumn{2}{c|}{ Total } \\
\cline { 2 - 7 } & $\mathbf{N}$ & Percent & N & Percent & N & Percent \\
\hline Bakas & 9 & $18 \%$ & 41 & $82 \%$ & 50 & $100 \%$ \\
\hline Neem & 9 & $18 \%$ & 41 & $82 \%$ & 50 & $100 \%$ \\
\hline Sisau & 7 & $14 \%$ & 43 & $86 \%$ & 50 & $100 \%$ \\
\hline Bhatpurain & 5 & $10 \%$ & 45 & $90 \%$ & 50 & $100 \%$ \\
\hline Kacchu & 6 & $12 \%$ & 44 & $88 \%$ & 50 & $100 \%$ \\
\hline Sarifa & 10 & $20 \%$ & 40 & $80 \%$ & 50 & $100 \%$ \\
\hline
\end{tabular}

Table 3: Sources of knowledge on plant species and their use by the respondents.

\begin{tabular}{|c|c|c|c|c|}
\hline Medicinal plants & Elders & Family tradition & Community knowledge & Traditional knowledge holders \\
\hline Bakas & 0 & 7 & 1 & 1 \\
\hline Bhatpurain & 1 & 2 & 0 & 0 \\
\hline Sarifa & 0 & 10 & 1 & 1 \\
\hline Kacchu & 0 & 4 & 1 & 2 \\
\hline Neem & 0 & 4 & 4 & 1 \\
\hline Sisau & 0 & & 1 & 0 \\
\hline
\end{tabular}

\section{Traditional Use of Medicinal Plants}

Altogether, 40 species of medicinal plants were identified as being used for traditional medicinal purpose in Sunsari district. Nepal is a good area to perform ethnobotanical field studies [6]. Nepal is comprised of 103 ethnic indigenous groups speaking more than 63 varieties of languages [7]. However, still 70-80\% of the population of the country depends upon medicinal plants for primary health care [2]. The high dependency of people on the use of medicinal plant for health care is due to poverty and traditional belief on its effectiveness [8-13].

\section{Conclusion}

Present study revealed that the local traditional healers of Sunsari district of Province No. 1 are rich in ethno-medicinal knowledge and majority of people rely on plant-based remedies for common health problems like headache, body ache, constipation, indigestion, cold, fever, diarrhea, dysentery, boils, wounds, skin diseases, urinary troubles, fractures, round worms, etc. The survey also revealed that all the traditional healers have strong faith on ethnomedicines although they were less conscious about the documentation and preservation of ethno-medicinal folklore and medicinal plants. The group discussion and personal interviews show that youngsters of both Malaha and Sardar communities and migrants are less aware about the use of ethnomedicine. On the other hand, traditional healers who are the main repository of ethno-medicinal knowledge claim extreme secrecy over their ethnomedicinal knowledge. The traditional healers have strong belief that if they disclose the secrecy about the medicinal properties of particular plant all the medicinal potentialities 
of the plant will be lost, and the remedy will not work properly. Ethno-medicinal use of plants in curing various diseases amongst the wetland dependent communities of KTWR is very important for first aid treatment. However, the existing knowledge with regard to the use and processing of medicinal plants is declining rapidly amongst the youth population. Hence, there is a dire need to document the wealth of accumulated traditional knowledge through a digital repository mechanism.

\section{References}

1. Yineger H, Yewhalaw D (2007) Traditional medicinal plant knowledge and use by local healers in Sekoru District, Jimma Zone, Southwestern Ethiopia. Journal of Ethnobiology and Ethnomedicine.

2. Manandhar NP (2002) Plants and People of Nepal. Timber Press Inc, Portland Oregon.

3. Gamedo-Dalle T, Maass BL, Isselstein J (2004) Plant biodiversity and ethnobotany of Borana pastoralists in Southern Oromia, Ethiopia. Springer 59(1): 43-65.

4. Balick MJ, Cox PA (1996) Ethnobotanical research and traditional health care in developing countries. Food and Agricultural Organization of the United Nations.
5. CBS (2001) Central Bureau of Statistics.

6. Rokaya MB, Münzbergová Z, Timsina B (2010) Ethnobotanical study of medicinal plants from the Humla district of western Nepal. Elsevier 130(3): 485-504.

7. CBS (2003) CBS Statistical Year Book of Nepal. Central Bureau of Statistics, Kathmandu, Nepal, India.

8. Shrestha PM, Dhillion SS (2003) Medicinal plant diversity and use in the highlands of Dolakha district, Nepal. Science Direct 86(1): 81-96.

9. Acharya KP, Acharya M (2009) Traditional knowledge on medicinal plants used for the treatment of livestock diseases in Sardikhola VDC, Kaski, Nepal. Journal of Medicinal Plants Research 4(2):235-239.

10. Bazzaz FA (1991) Habitat Selection in Plants. JSTOR pp. S116-S130.

11. Edwards R (2004) No remedy in sight for herbal ransack. New Scientist.

12. Ekor M (2014) The growing use of herbal medicines: Issues relating to adverse reactions and challenges in monitoring safety. US National Library of Medicine.

13. Uprety Y, Asselin H, Boon EK, Yadav S, Shrestha KK (2010) Indigenous use and bio-efficacy of medicinal plants in the Rasuwa District, Central Nepal. Journal of Ethnobiology and Ethnomedicine.

This work is licensed under Creative Commons Attribution 4.0 License DOI: $10.19080 / I J E S N R .2018 .15 .555924$ 